\title{
YOUTH MINISTRY IN THE 21ST CENTURY FIVE VIEWS
}

$\mathbf{M}$ odel apakah yang paling tepat untuk diterapkan pada pelayanan kaum muda masa kini di abad ke21? Pertanyaan ini adalah pertanyaan yang sering kali ditanyakan oleh para pemimpin gereja, khususnya pemimpin kaum muda di gereja. Pertanyaan ini muncul karena adanya kebingungan di dalam gereja seiring dengan menurunnya jumlah partisipasi anak muda di dalam gereja. Gereja-gereja yang sadar akan hal ini, mulai mencari model baru di dalam menjalankan pelayanan kaum muda. Model lama yang dulu pernah sukses di zaman sebelumnya tampak sudah mulai tidak relevan lagi di zaman kini.

Pertanyaan inilah yang ingin dijawab di dalam buku "Youth Ministry in the 21 ${ }^{\text {st }}$
Century: Five Views". Maksud utama dari buku ini adalah untuk menawarkan lima model yang unik tentang bagaimanakah pelayanan kaum muda harus dikerjakan kini dan di dalam dekade ke depan. Namun, buku ini tidak sedang mencari model manakah yang paling benar dari kelima model yang ditawarkan, melainkan memberikan tempat agar suara mereka dapat didengarkan dan memunculkan sebuah percakapan di dalam menggumuli pertanyaan model apakah yang tepat bagi pelayanan kaum muda di abad ke-21?

Model pelayanan kaum muda yang pertama, diusulkan oleh Greg Stier: The Gospel Advancing View of Youth Ministry. Stier mengkritisi pelayanan kaum muda yang hanya berpusat pada

1. Alumnus STT Ebenhaezer Tanjung Enim (2008); STT Amanat Agung Jakar (2017) dan sekarang melayani sebagai youth pastor GKBJ Kelapa Gading, Jakarta. 
kegiatan dan pertemuan. Melalui model ini, Stier ingin menjadikan Injil dan penginjilan sebagai penggerak dan pusat dari pelayanan kaum muda. Ia menghubungkan antara praktik penginjilan dengan kemuridan bahwa penginjilan akan mempercepat proses pemuridan. Ia mengatakan: "when we lead the way for evangelism personally and equip teenegers to do the same, it accelerates the discipleship process faster than just about anything." Tujuan utamanya bukanlah program penginjilan itu sendiri, melainkan membina remaja untuk hidup dan membagikan Injil di dalam perkataan dan tindakan mereka secara disengaja. Model ini berusaha membawa kaum muda untuk memiliki relasi yang lebih dalam dengan Tuhan ketika mereka membawa Kabar Baik ke tempat yang lebih luas kepada yang terhilang. Jadi, semua bentuk pelatihan di dalam pelayanan kaum muda harus diarahkan untuk pergi ke tempat yang lebih luas dan misi yang membawa mereka ke tempat yang lebih luas harus membawa mereka untuk semakin dalam di dalam relasi mereka dengan Tuhan.

Model pelayanan kaum muda yang kedua adalah The Reformed View of Youth Ministry oleh Brian Cosby. Ia mengkritisi bahwa hilangnya para pemuda usia kuliah merupakan fenomena ketidakberesan yang ada di dalam pelayanan remaja usia SMA, dan mengkritisi usaha untuk merasionalisasi penggunaan entertainment sebagai jalan masuk untuk menarik dan membawa anak muda masuk ke dalam pintu gereja. Baginya "you keep them by how you attract them."
Penggunaan entertainment di dalam komunitas gereja hanya meninggalkan anak remaja dan anak muda ke dalam kondisi "ketidakpuasan, kehampaan dan kesendirian." Jiwa mereka tetap kosong.

Model ini dimotivasi oleh semangat untuk menerapkan metodologi Reformed secara konsisten yang terekspresi melalui sarana kasih karunia (means of grace) di sepanjang sejarah gereja, yaitu sebuah model yang setia dengan tradisi Reformed (yang baginya adalah model yang paling alkitabiah) yang menjadikan sarana kasih karunia (means of grace) sebagai alat yang melaluinya Allah menyelamatkan dan menguduskan umat-Nya, yaitu pelayanan Firman, Doa, Sakramen (Baptisan dan Perjamuan Kudus), pelayanan Diakonia, dan komunitas orang percaya.

Ia menegaskan bahwa "faithfulness to God is always more important than success in ministry." Teori dan praktik pelayanan harus berasal dan diafirmasi oleh Alkitab. Kesetiaan ini lebih penting dari pada kesuksesan di dalam pelayanan. Ia mencoba mengembalikan pelayanan kaum muda kepada makna yang dalam yang berakar pada teks Alkitab dan doktrin gereja serta tradisinya. Namun, penekanannya pada konteks tampaknya agak lemah. Ia ingin pelayanan kaum muda tidak terjebak ke dalam sebuah pelayanan yang "mere entertaining yet purposeless."

Model pelayanan kaum muda yang ketiga adalah The Adoption View of Youth Ministry oleh Chap Clark. Ia mengatakan bahwa pelayanan kaum muda sering kali menjadi gereja kecil di dalam gereja dan tanpa sadar menciptakan anak muda yang 
individualistik. Penekanan pada "menerima Yesus sebagai Tuhan dan Juruselamat pribadi" dan disiplin rohani pribadi, termasuk di dalamnya model mentoring "one-on-one" tanpa menanamkan pentingnya keberadaan komunitas gereja dalam perjalanan iman orang muda, menjadi salah satu penyebab bagi anak muda meninggalkan gereja, karena mereka merasa tidak memiliki ikatan yang kuat dengan gereja. Ia juga mengkritisi pelayanan gereja yang terjebak di dalam programmatic model yang tersegmentasi. Hasilnya relasi di dalam gereja menjadi terfragmentasi dan terisolasi.

Clark melihat bahwa gereja perlu mengadopsi anak remaja dan anak muda di dalam gereja sehingga mereka tidak dilihat sebagai komunitas yang terpisahkan dari gereja tetapi sebagai bagian dari keluarga gereja. Ia mendasari model ini berdasarkan metafora Alkitab tentang gereja sebagai tubuh dan keluarga. Setiap anggota tubuh atau anggota keluarga di dalam gereja saling membutuhkan dan melengkapi. Gereja menjadi a family of families. Pemimpin senior gereja tidak lagi hanya sekadar menjadi penyedia apa yang dibutuhkan oleh orang muda dalam pelayanan kaum muda, tetapi sungguh hadir di dalam perjalanan iman orang muda sambil mereka mengembangkan kedewasaan iman dan kemampuan mereka di dalam berelasi secara interdependen.

Secara praktis Clark juga menggambarkan pengaplikasian model ini. Contohnya ketika seorang pemimpin kelompok kecil menemukan ada seorang anak SMA yang memiliki kemampuan dan keterta-

\section{Pemimpin senior gereja tidak lagi hanya sekadar menjadi penyedia apa yang dibutuhkan oleh orang muda dalam pelayanan kaum muda, tetapi sungguh hadir di dalam perjalanan iman orang muda sambil mereka mengembangkan kedewasaan iman dan kemampuan mereka di dalam berelasi secara interdependen.}

rikan dalam urusan teknik audio. Pemimpin itu harus menghubungkan anak SMA itu dengan tim yang bertanggung jawab terhadap pelayanan sound production di dalam ibadah gereja. Namun, hal ini bukanlah untuk "memanfaatkan" talenta atau ketertarikan anak SMA tersebut atau untuk memberikan tanggung jawab pelayanan kepada anak tersebut, tetapi tim sound production memiliki tugas untuk mengadopsi anak SMA itu sebagai anggota dari keluarga Allah di dalam gereja lokal tersebut. Berdoa, berbagi dan studi Alkitab bersama di dalam tim harus juga menjadi bagian di dalam pengadopsian tersebut. Anak SMA itu tidak hanya akan mampu melayani di bidang itu dan mengalami pertumbuhan iman secara pribadi tetapi ia juga akan merasakan sebuah ikatan yang kuat dengan keluarga besarnya di dalam gereja lokal tersebut. Seluruh tim juga akan mengalami sebuah pengalaman pelayanan yang menggairah- 
kan. Setiap anak muda penting. Setiap anak muda diterima dan merupakan bagian dari keluarga besar Allah dalam gereja lokal Setiap anak muda tidak hanya dimentoring oleh satu orang mentor yang sudah dewasa, tetapi ia akan mengalami apa yang Clark sebut sebagai "a mentoring community."

Model pelayanan kaum muda yang keempat adalah The Ecclesial View of Youth Ministry oleh Fernando Arzola. Jika Chap Clark dengan model Adoption menekankan pada relasi antar generasi di dalam jemaat lokal. Arzola melangkah lebih jauh dengan menekankan pada relasi antara pelayanan kaum muda kini dengan gereja di sepanjang sejarah. Ia melihat bahwa gereja masa kini sudah terjebak di dalam pengaruh buruk yang diwarisi dari abad pencerahan, yaitu penekanan pada pragmatisme, di mana gereja mengadopsi model-model dari dunia bisnis dan mengaplikasikannya di dalam gereja demi tujuan keefektifan, dan penekanan pada individualisme, bahwa pemuridan, penyembahan dan khotbah di dalam gereja semuanya hanya diarahkan kepada pertumbuhan rohani seseorang secara individu.

Dalam tulisannya, Arzola mengusulkan sebuah konsep eklesiologi yang sering diabaikan di dalam pelayanan kaum muda. Pelayanan kaum muda yang hanya berfokus pada unsur praktis seperti pemuridan dan pujian penyembahan, perlu memahami konsep eklesiologi yang ada di dalam perjalanan panjang sejarah gereja. Namun, secara khusus ia menekankan pentingnya eklesiologi dari gereja abad mula-mula karena dianggap memiliki keterikatan yang kuat dengan masa kehadiaran Kristus di bumi. Eklesiologi dari abad mula-mula dianggap yang paling murni untuk membangun sebuah pelayanan gereja. Eklesiologi ini harus menjadi dasar untuk membangun sebuah pelayanan kaum muda.

Pemahaman yang tepat tentang eklesiologi dan sejarah gereja akan mencegah pemimpin kaum muda untuk menciptakan sebuah pelayanan gereja yang hanya didasari oleh karakter dan tempramen pemimpin. Eklesiologi ini harus menjadi presuposisi dan teori di dalam membangun model pelayanan kaum muda. Hal yang disayangkan dari apa yang diusulkan oleh Arzola adalah bahwa ia hanya berfokus pada teori. Ia tidak mengusulkan sebuah model pelayanan kaum muda ini secara praktis.

Model pelayanan kaum muda yang kelima adalah The D6 View of Youth Ministry oleh Ron Hunter. Ada dua masalah yang disoroti oleh Hunter sebagai latar belakang dari model pelayanan kaum muda yang ia usulkan. Pertama, adanya segregasi dan isolasi di antara masingmasing bidang pelayanan di dalam gereja. Keduanya, adanya kecenderungan gereja untuk mempekerjakan pekerja yang khusus ditempatkan sebagai pelayan kaum muda, pelayan anak, dan lain-lain. Menurut Hunter, hal ini tidaklah salah, namun hal ini menjadi sebuah masalah jika orang tua mendelegasikan semua tanggung jawab pertumbuhan rohani anaknya kepada pelayan-pelayan ini. Hal ini justru berdampak pada kurangnya interaksi

\section{Youlfh | Mei 2016}


antara orang tua dengan anak dan orang tua kehilangan pengaruh bagi anak mereka sendiri.

Kedua masalah ini akan membawa anak muda hilang dari gereja dan menghidupi prinsip-prinsip hidup yang tidak berpusat pada Kristus. Hunter mengusulkan model pelayanan kaum muda yang ia sebut sebagai D6 sebagai solusi bagi masalah ini. D6 adalah akronim dari Deuteronomy 6 (Ulangan 6) - dan juga Efesus 6 - sebagai dasar biblika dari model pelayanan ini. Dalam Ulangan 6 dan Efesus 6, Allah memerintahkan generasi yang lebih tua (kakak-nenek, orang tua, komunitas iman) sebagai satu kesatuan untuk memuridkan generasi berikutnya dengan memberikan teladan dan pengajaran yang berulang-ulang, dan tidak mendelegasikan tanggung jawab ini kepada orang lain.

D6 merupakan sebuah model pelayanan terhadap kaum muda di mana semua pemimpin gereja dan semua orang tua saling bermitra untuk mempersiapkan generasi berikutnya demi kehidupan mereka ke depan. Gereja dan rumah harus terus-menerus memuridkan generasi muda. Secara praktis, model pelayanan D6 dapat diaplikasikan demikian: pertama, pendeta kaum muda berperan sebagai seorang transformational leader, yang berfokus pada pembaharuan hidup orang yang ia pimpin. Ia akan memimpin dan menggembalakan kelompok anak muda serta (bersama gembala dan pemimpin lainnya di dalam gereja) memberikan pengaruh dan melatih (coaching) orang tua untuk menjadi coach yang memuridkan anak mereka juga. Pendeta kaum muda harus mengajak orang tua untuk terlibat dalam pembicaraan tentang halhal rohani dengan anak remaja mereka, dengan cara mengajarkan mereka bagaimana memberikan pertanyaan yang tepat dan bagaimana menunjukkan kasih yang tanpa syarat. Orang tua harus diingatkan bahwa tidak semua pembicaraan harus berisi kritikan, ceramah Alkitab atau harus selalu serius. Kedua, pendeta kaum muda dan pelayanan kaum muda tidak dapat memposisikan dirinya lebih cool dari orang tua anak remaja yang ia bimbing dan dari pelayanan umum gereja, karena mereka akan meremehkan orang tua mereka dan tidak menyukai gereja secara umum. Ketiga, orang tua pun akan belajar dari gereja melalui khotbahkhotbah, kelompok kecil, kelas-kelas pembinaan dan relasi di dalam gereja, sehingga orangtua dapat menyediakan sebuah pemuridan yang konsisten kepada anak mereka ketika mereka di rumah. Pemuridan yang konsisten (with grace and trust) di dalam sebuah relasi yang sangat dekat antara orang tua dan anak akan menghasilkan sebuah pengaruh yang luar biasa untuk hidup seorang anak. 